\title{
INTUSSUSCEPTION.
}

DR. L. A. Greensfelder reported the case of a man, aged eighteen years, who walked into the lospital, August II, 1904. On admission at 3 P.M., the following history was obtained: Illness began six days ago, with a sudden, severe pain in the epigastric region, with nausea, vomiting, and constipation. Patient then consulted a plysician, who prescribed castor oil, magnesia, ete, all of which the paticnt promptly vomited. During the first three days of the attack patient liad a number of loose, watery bowel movements, witl continual vomiting. The three days prior to admission was constipated. The pain in last few days become localized in the right iliae region. No chills, no headaches, eannot sleep, and has vertigo when lie walks. Past history was negative. Never had a similar attaek. No sickness of consequenee.

Physieal examination of abdomen revealed a tumor in the right iliae region. The abdomen was not tympanitie, and the tumor mass eould be felt by reetum. Temperature, $98.8^{\circ} \mathrm{F}$.; pulse, II4; respirations, 24.

Urinaly'sis.-Speeific gravity, 1031; urea, 3.0 per eent.; no albumen; no sugar; indiean present. Letucoeytes few. No casts.

White blood eount, 15,400 at 4 I.M. ; I 5,200 at 7 P.M. High rectal tube was introdueed; no fatus was passed. He was given a low pressure enema, after whieh considerable blood was passed. Nothing was given by moutl, but reetal feeding of peptonized milk and beef peptonoids was given every six hours. Iee-bag to abdonen during first twelve hours. 'Temperature remained at $100^{\circ}$ I.; pulse, 82 to 88 . Had a slight bowel movement at 4 A.M. and 7 A.M., with flatus and considerable blood.

August 12. Temperature, $988^{\circ} \mathrm{F}$; pulse, 82 ; respirations, 24. Amount of urine in twenty-fonl liours, thirteen ounces. Urinalysis negative. White blood count, 12,600. One bowel movenent at 9 P.M. and anotlier at Io P.M., both containing blood.

August 13. At 2 A.A. vomited considerable amount of brownish fuid. At 4 A.M. conılained of severe pain in right iliac region; abdomen was slightly rigid; pulse, 84 ; temperature, $99^{\circ}$ F.; respirations, 24 . At II.30 A.M. was taken to the operating room. Under ether anesthesia, a four-inch incision was made along outer border of right reetus. As soon as peri- 


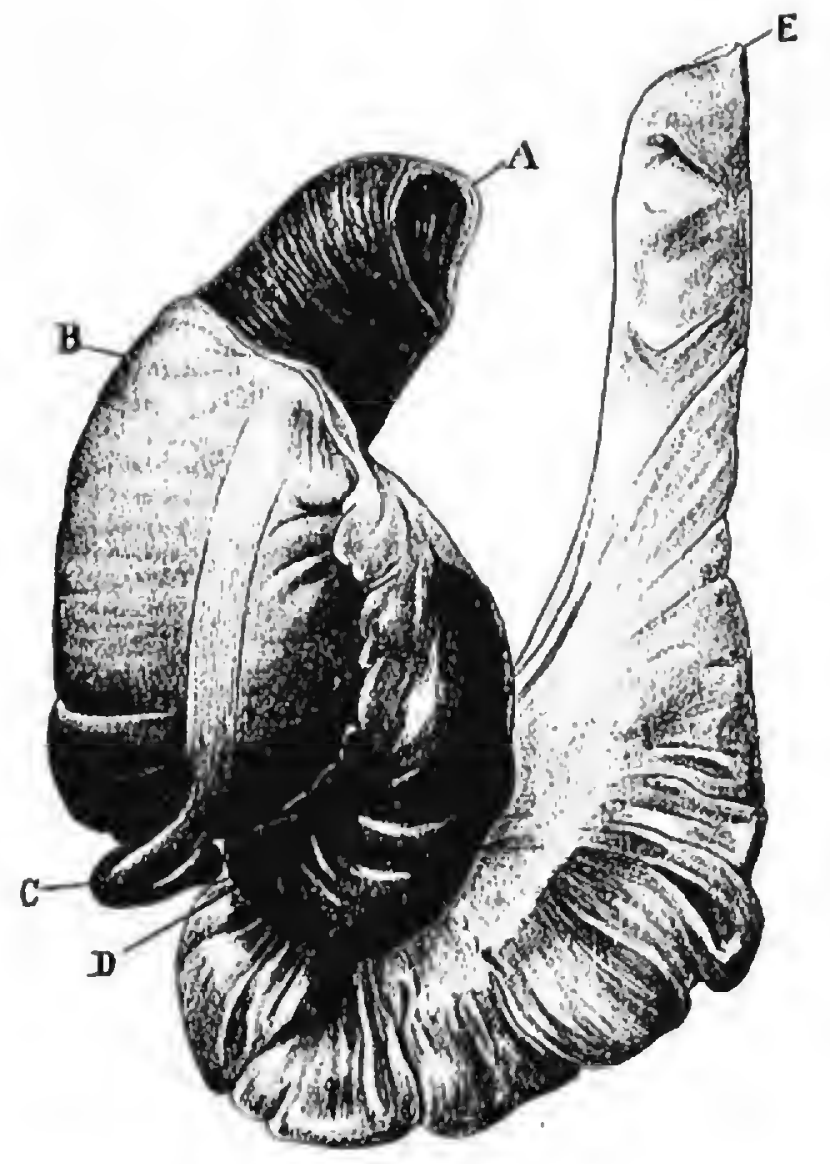

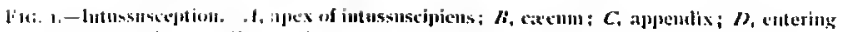

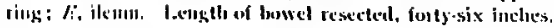


toneum was opened, an intussuseeption (Fig. 1) was found at the ileocxcal valve, and lifted out of the abdomen. The small bowel entered the large bowel for a distance of about six or seven inches. Bowel was found to be gangrenous for about three feet. The gangrenous portion, eonsisting of ileum and eolon, was resected by clamping off the gangrenous portion with two elamps at eaeh end and dividing between. The mesentery was clamped off and cut; all bleeding points arrested; the bowel was kept warm by the applieation of hot sponges, and edges of wound protected by gauze packing. The cut end of the colon was then closed by two layers of eatgut sutures, one penetrating all the coats of the bowel and the second by a Lembert suture. Mesentery was next sutured. Repeated attempts were then made to place a purse-string suture around the cut end of the ileum and introduce a Murply button, but the tissues were so friable that it was found impossible. The cut end of the ileum was then sutured to the abdominal wall, forming an artificial anus. Rubber tube was inserted into small bowel through artificial anus, and skin incision closed with silk sutures. A Mikulicz drain was inserted just below artificial anus, and dry gauze. dressing applied. Patient put to bed in a very exhausted condition. Operation lasted two hours and ten minutes. A pint of normal salt solution was infused under each breast. Camphor in ether and strychnine sulphate were administered. Pulse, 164; temperature, $102^{\circ} \mathrm{F}$; respirations, 28 . Dressings were saturated with facal discharges frequently during the first six hours.

August 14. Temperature, 103.6 F.; pulse, I 20 to 140; respirations, 28. Forty ounces of urine were voided in past twenty-four hours. Urinalysis negative. Patient taking water, milk, and Viehy by moutl. Had a comfortable night. Considcrable freal discharge through tube.

August 15. Temperature, $101^{\circ} \mathrm{F}$.; pulse, 100 to 120 ; respirations, 24. Complains of eough. Drank coffec, milk, Vichy, and water. Twenty-eight ounces of urinc.

August 16. Temperature, $100^{\circ} \mathrm{F}$; pulse, 96 to 100 ; respirations, 24. Paticnt has taken broth, milk, and Vichy.

Urine, twenty-two ounces. Urinalysis negative. Mikulicz packing removed, and one gauze drain insertcd into wound. A number of bowel movements through artificial anus. 
August 17. Temperature, $99^{\circ} \mathrm{F}$; pulse, 82 ; respirations, 22. Wound redressed three times. Urine, twenty-nine ounees.

August 18. Temperature, $98.6^{\circ} \mathrm{F}$.; pulse, 84 ; respirations, 24. Urine, thirty ounces. Frequent elianges of dressing were required.

August 19. Temperature, $98.6^{\circ} \mathrm{F}$; pulse, 80 ; respirations, 24. Patient taking riee soup, egg, milk, and tea.

Patient then eontinued with normal temperature and pulse, but on aeeount of a severe dermatitis of abdomen and infection of skin edges of the wound, the seeond operation was delayed until eonditions were more favorable.

On September 19, 1904, thirty-eight days after his first operation, the patient was again anæsthetized, and the following operation performed by Dr. E. Wyllys Andrews:

An incision about five inches long was made just to right of reetus muscle, begiuning about an inelh below costal arelh, and earried through museles and peritoneum. When intestines were exposed, it was found that extensive adhesions lad formed between omentum and intestines. These were partly freed and the colon was brouglit into view. The artificial anus was obliterated by cutting the skin around anus and elamping ileum, which formed the anus. The part above elamp was severed and ileum ligated with strong eatgut, and stump covered with Lembert suture. Then a portion of the aseending colon and ileum were brought into view and Lembert suture silk united their serous surfaees. Then incisions were made into eolon and ileum, about one and a half inelies long, and eut edges united by a Connell suture. The Lembert suture was now continued, and knot tied within lumen of bowel. The omentum was laid over bowel. Iodoform gauzc drains were inserted at the site of the artificial anus, and peritoneum was elosed with interrupted eatgut sutures. Skin elosed with silkworm gut and horsehair sutures. Dry gauze dressing applied.

Patient experieneed no shoek from operation, and following day temperature was $99^{\circ} \mathrm{F}$; ; pulse, 88; respirations, 20.

August 25. Had first bowel movement. Temperature and pulse have been normal sinee.

November 4. There is a very small fistula, whieh contains a drainage tube. Patient is up and in good condition.

Dr. E. Wyllys Andrews said that the matter of friability 
of the intestine had been called to his notiee in at least two cases, which seemed to be more analogous to a fat neerosis or some kind of degeneration than to peritonitis. In the case reported by Dr. Greensfelder great diffieulty was cxpcrieneed in bringing the intestine out and attaching it to the button, or even to the abdominal wall, by reason of the extreme softncss. It would not hold stitches, and this mere mechanieal difficulty prolonged the operation very materially. At the time the speaker saw the patient later, when a Connell suture anastomosis was made, there was no such trouble.

A similar case to this was reported to him by Dr. Morgan, in which the stomach wall was very friable. It was a gall-stone ease, and in manipulating the gall-bladder gently the finger of the operator torc dircetly into the stomach, making a large opening. It not only torc as wet paper would tear, but it was impossible to suture with needle or evcn pick up the tissue with forccps afterwards. The slightest touch would tear through it. He never saw the stomaeh in that condition before. He attributed it to fat neerosis generalized over the adjacent organs. This was probably a casc of pancreatitis, the generalized fat nccrosis extending to and involving the stomach wall. He was quite sure that peritonitis alone, or merc hypertrophy and distention of the hollow visccra above a point of obstruetion, could hardly explain the eondition.

Dr. Albert J. Ochisner showed a speeimen from a case of intussusception. The patient was a ehild, fiftecn years of age, in whom a diagnosis of intusstseeption was made seven days after opcrating for an acute' appenticitis. He thought the intussusception was about eight days old when a diagnosis was made, and that the appendicitis was an unimportant part of the condition for which the patient was operated first. In other words, the first diagnosis was wrong, at least so far as the serious condition was coneerned.

DR. YATES stated that about three years previous to admission to the hospital the patient was supposed to have had an acute attack of inflammation of the bowels. There were bloody stools, etc. The patient's recovery from this attack was rather rapid. The second intussusception took place in the ileum; the invaginated portion was fifty-two centimetres long. It had existed long enough for the intussusceptum to become gangrenous, so 
that the intussuseipiens protruded through the wall of the intussusceptum.

Two days after the onset of the seeond attaek, the patient was sent to the hospital by his physieian with a diagnosis of appendieitis, whieh was confirmed and an inmediate operation performed. Upon opening the abdomen, Dr. Oelssner notieed an excess of serum, whielı was the only feature not referable to the appendieular condition. The boy did not reaet well after the operation, and beeause of nausea received but limited amounts of water by mouth. This masked the symptoms by controlling peristalsis.

At the second operation, a wcek later, it was found that the gangrenous portions of the intussuseeption had been completely walled off from the general peritoneal cavity by adhesions formed by contiguous loops of intestine and the onentum and preventing a gencral peritonitis. The gangrenons portions had acted as a foreign body, produced a localized peritonitis which the abscnce of vermicular intestinal movements had allowed to beeome enclosed in the adhesions thus stimulated. On the twelfth day symptoms of obstruction reappeared, and an enterostomy was done for its relief. Death oecurred the next day, with no evidence of a general peritonitis.

DR. JACOB FrANK said that abont two years ago he reported a case of intussusception of the ileum into the crecum in a child nine months of age, in whom he resorted to the use of the button, the child making a complete recovery. He showed the ehild before the Soeiety one year after the operation.

With regard to sutures not holding when the intestine was friable, this was seen in eases of appendicitis when the intestine was œclenatouis. One could with diffieulty get the sutures to remain in plaee without entting throngh. In cases of intestinal disease in the acute stage where there was an celematons or inflammatory condition, this was almost always found to be the case. He did not think it was duc to pancreatitis or to fatty embolus. If it were, he thought we wonld have more deaths. He had found it in a large pereentage of eases of appendieitis where the temperature ran high and where there was gangrene of the appendix.

Dr. D. A. K. Steele said that one point of interest in regard to the first case presented was the persistence of the intestinal 
fistula, and whether that might not have been due to some foreign material retained in the abdominal cavity, or in connection with the inner end of the fistulous tract. Possibly the presence of the Connell suture might explain the persistence of the fistula.

With reference to the friability of the intestine and the difficulty of stutures holding, his experience had been the same as that of Dr. Frank. In many cases of acute infammatory conditions of the intestine, partienlarly in appendicitis, and pustubes or infected tubes in women, there was great odema of the adjacent parts, and the explanation given was correct, namely, that it was due to alteration in the wall of the intestine or tube from merely cedema. Dry paper did not tear easily, but if one would wet it, it would tear easily. The same thing could be said of the bowel wall in the same condition.

Dr. L. L. McArtilur said that it was to Koenig that credit was due for cimpliasizing the faet that the bowel was friable above the seat of obstruetion far beyond that which appeared to the naked eye, and venous septic thrombosis was liable to occur which would terminate fatally, althougl there may have been perfeet suturing, the bowel being friable the nearer it is to the gangrenous area, altlouglı being vascular and its nutrition not being materially impaired. These cases lie (Koenig) said would die in spite of perfect suturing from a septic thrombophlebitis in that portion of the bowel above, which laal not been exeised far enough beyond. It was a wise thing to go 11 uch farther above than appeared neessary to get a good suture field for the purpose of getting beyond a venous thrombophlebitis, which would searecly show externally, but which would show when one saw the mucosa and submucosa of that portion of the bowel. Cases of mesenteric thrombosis were extremely rare, and were of considerable interest because of the great difficulty of making a diagnosis before operation. He had oecasion to look up the literature in regard to this stbject at one time, some years ago, in presenting a paper to the Chicago Medical Society, and could only find a record of two cases in which the diagnosis was made before operation. In the case reported by Dr. Greensfelder, that lived to the fifth or nearly sixth day, Dr. Greensfelder did not state from what the patient died, whether there was leakage at the point, or whether the superior mesenteric artery, which sup- 
plied the entire small intestine and transverse colon, had produeed gangrene beyond that portion which had been resected.

Dr. GREENSFELDER, in answering the question of Dr. Steele, stated that there was no intestinal fistula at present.

In regard to the remarks of Dr. MeArthur, in the patient who had thrombosis of the mesenteric artery there was complete gangrene extending not only to the small bowel, but to part of the colon; death occurring undoubtedly from this condition.

Regarding the statistics of mesenteric thrombosis, he stated that 217 eases had been reeently reported by Jaekson, Porter, and Quinby in Journal of the Anerican Medical Association, with a mortality of 94 per eent. in non-operated eases, and a mortality of 92 per cent. in the cases operated upon.

\section{PERINEAL PROSTATECTOMY.}

DR. JACOB FrANK reported the ease of a man, aged seventy years, who consulted him at his office, May 15, 1904, complaining of laving been troubled with frequent and painful micturition for nine nonths, passing very little urine at the time; and after having had to resort to the use of a eatheter several times at intervals during this period, had been eompelled to lead daily eatheter life for the past five montlis, suffering agonizing pains, insomnia, anorexia, unbearable pain in bladder, loss in weight, a great deal of residual urine,-quantity in twenty-four hours, fifty-eight ounces, specifie gravity, I023. Albumen present; no sugar; abundanee of pus-cells; also some squamous cells; reaetion acid; no blood; urea, 2.I per eent. in twenty-four hour specimen.

Patient was sent to the German Hospital, May 29, 1904. He was put to bed; kept on a striet liquid diet; urotropin, five grains, every four hours; lithia water in plenty; boric aeid irrigation of bladder daily at a temperature of $110^{\circ} \mathrm{F}$., and the daily use of the prostatie eatheter, as the ordinary soft rubber one eould not be introduced; normal salt solution twice daily per rectum, as the patient was emaciated and required careful nursing.

The prostate gland could easily be palpated via the abdomen; the lateral lobes were greatly enlarged and very tender. The operation was performed June 2, 1904, four days after admission to the hospital, under chloroform. The patient was put in exag- 